\title{
Miopia informacional
}

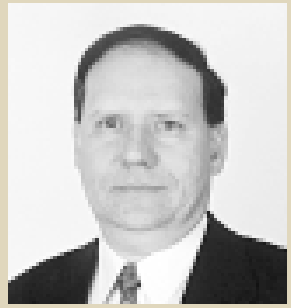

José Luiz Kugler FGV-EAESP

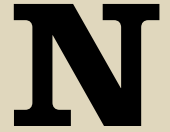

os últimos anos, os clientes se transformaram em alvos móveis e temperamentais que exigem ajustes constantes nas táticas de aproximação, comunicação e atendimento.

Que o digam as empresas virtuais, cuja vantagem competitiva vem sendo construída sobre a customização dos serviços que oferecem, amparada pela compreensão precisa das necessidades de seus consumidores.

Ainda que utilizem poderosas ferramentas informatizadas de relacionamento com clientes, muitas empresas possuem apenas um entendimento fragmentado do perfil de seus consumidores, transformados em meras referências nos relatórios de desempenho.

A questão importante não se refere à adoção dessa ou daquela ferramenta de informática, mas à ampliação da compreensão do modelo mental dos consumidores. Esse modelo refere-se a um longo ciclo, que envolve coleta, interpretação e avaliação de informações efetuada pelo consumidor no relacionamento com um fornecedor de produtos ou serviços.

0 modelo mental funciona como um filtro que seleciona os produtos ou serviços percebidos como capazes de proporcionar um valor superior. Porém, o consumidor não avalia apenas as características intrínsecas do produto ou serviço; ele avalia uma cadeia completa de interações, que antecede a compra e estende-se além do uso.
Tomemos o exemplo dos espetáculos esportivos. Eles parecem concebidos e gerenciados em função do que ocorre em campo: numa partida de futebol, os 90 minutos de jogo são controlados por regras restritas. Porém, no período que antecede 0 apito inicial e no que sucede 0 apito final, vive-se sob o caos. Para assistir a uma partida, o torcedor enfrenta problemas de transporte, estacionamento, alimentação e segurança. Muitos concluem que o espetáculo não compensa os problemas enfrentados antes e depois dele.

$\mathrm{Na}$ era digital, a gestão de clientes demanda mais do que instalação de softwares de relacionamento, que, aliás, são imprescindíveis e permitem 0 acúmulo de informações preciosas para as empresas. Porém, sua utilização só gerará benefícios se forem aplicados ao modelo mental adequado do consumidor. Infelizmente, muitas empresas se deixam fascinar pelos recursos tecnológicos e investem grandes somas em soluções de caráter reducionista, que restringem, ao invés de ampliar, a percep ção das necessidades do consumidor.

0 foco no modelo mental permite mapear e interpretar adequadamente o perfil do consumidor. A definição das ferramentas deve vir depois. Exemplos são os bancos e supermercados virtuais, queeliminam filas eeconomizam o tempo cada vez mais escasso de seus clientes. 0 sucesso desses produtos se ampara na correta compreensão dasnecessidades eexpectativas do consumidor que vive nas modernas cidades da atualidade. 